\title{
ANTICORPOS ANTI-LEPTOSPIRA SPP. EM OVINOS DO MUNICÍPIO DE MONTE NEGRO, ESTADO DE RONDÔNIA
}

\author{
D.M. Aguiar', G.T. Cavalcante², S.A. Vasconcellos², G.O. Souza², \\ M.B. Labruna ${ }^{2}$, L.M.A. Camargo ${ }^{3}$, S.M. Gennari ${ }^{2}$
}

${ }^{1}$ Universidade Federal de Mato Grosso, Faculdade de Agronomia e Medicina Veterinária, Departamento de Clinica Médica Veterinária, Av. Fernando Correa da Costa s/no, CEP 78060-900, Cuiabá, MT, Brasil. E-mail: danmoura@ufmt.br

\section{RESUMO}

O presente estudo determinou a prevalência de anticorpos anti-Leptospira spp. em ovinos do Município de Monte Negro, RO. Foram examinados soros de 141 ovinos de raça, idade e sexo variados provenientes de 15 fazendas, pela técnica de Soroaglutinação Microscópica. Doze (80,0\%) propriedades apresentaram pelo menos um animal reagente. Títulos de anticorpos iguais ou superiores a 100 foram detectados em 47 (33,3\%) animais, e os sorovares mais frequentes foram Patoc (29,7\%), Autumnalis (14,8\%), Pyrogenes (10,6\%), Australis (4,2\%), Bratislava (4,2\%), Hardjo $(4,2 \%)$, Icterohaemorrhagiae $(4,2 \%)$, Castellonis $(2,1 \%)$ e Hebdomadis $(2,1 \%)$. Em $11(23,4 \%)$ soros não foi possível a determinação do provável sorovar envolvido na reação. Alerta-se também para a possibilidade de infecção no homem, tendo em vista as características regionais de fronteira agrícola amazônica.

PALAVRAS-CHAVE: Ovinos, leptospira, prevalência, sorovar, Amazônia, Brasil.

\section{ABSTRACT}

ANTI-LEPTOSPIRASPP.ANTIBODIESINOVINESFROMMONTENEGROMUNICIPALITY, RONDONIASTATE, BRAZIL. The present study determined the prevalence of anti-Leptospira spp. antibodies in 141 ovines from 15 farms of the Monte Negro Municipality, Rondonia State, Brazil, by the microscopic agglutination test. Twelve (80.0\%) farms presented at least 1 reactive animal. Antibodies titers of $\geq 100$ were detected in $47(33.3 \%)$ animals, the most frequent serovars being Patoc (29.7\%), Autumnalis (14.8\%), Pyrogenes (10.6\%), Australis (4.2\%), Bratislava (4.2\%), Hardjo (4.2\%), Icterohaemorrhagiae (4.2\%), Castellonis (2.1\%) and Hebdomadis (2.1\%). In 11 (23.4\%) sera it was not possible to determine the most frequent serovar involved. The results raise a warning as to the possibility of infection in the human being by Leptospira in light of the regional characteristics of the Amazon agricultural frontier.

KEY WORDS: Ovine, leptospira, prevalence, serovar, Amazon, Brazil.

A leptospirose é uma doença infecto-contagiosa, de caráter zoonótico, relacionada a perdas econômicas nos animais devido à redução do desempenho reprodutivo dos rebanhos acometidos. Todas as espécies animais e os homens são sensíveis às leptospiras. Nos ovinos a doença é rara, pois esta espécie é menos susceptível, gerando frequentemente evolução assintomática. Os animais quando infectados por leptospiras patogências podem apresentar febre, dispneia, hemoglobinúria, mucosas pálidas e icterícia. Casos mais graves podem ocorrer ocasionando, principalmente, surtos da doença com abortamento e morte de cordeiros (RADOstiTs et al., 2000).

O sorovar Hardjo é o mais frequente em bovinos e ovinos em todo o mundo, portanto o maior causador de problemas reprodutivos em ovelhas e de morte de cordeiros. No Brasil, outros sorovares já foram descritos como responsáveis por reações sorológicas, como Australis, Autumnalis, Bratislava, Butembo, Canicola, Castellonis, Grippotyphosa, Hebdomadis, Icterohaemorrhagiae, Pyrogenes, Pomona e Tarassovi (HerRmann et al., 2004; FÁVERo et al., 2002).

${ }^{2}$ Universidade de São Paulo, Faculdade de Medicina Veterinária e Zootecnia, Departamento de Medicina Veterinária Preventiva e Saúde Animal, São Paulo, SP, Brasil.

${ }^{3}$ Instituto de Ciências Biomédicas V, Núcleo Avançado de Pesquisa, Monte Negro, RO, Brasil. 
As regiões tropicais e subtropicais são mais favoráveis que as temperadas para a ocorrência da leptospirose, visto que o gênero Leptospira pode sobreviver por longos períodos em ambientes úmidos, o que aumenta o risco de exposição e infecção de animais susceptíveis (AcHA; SzYFres, 2001). Nesse sentido o Estado de Rondônia, situado na região da Amazônia Ocidental Brasileira, apresenta condições propícias para a manutenção desse agente em virtude das condições edafoclimáticas regionais. Como a ocorrência de anticorpos anti-Leptospira spp. em ovinos ainda é pouco conhecida na região, o presente estudo objetivou determinar a prevalência de anticorpos anti-Leptospira spp. em ovinos de propriedades rurais que desenvolvem agricultura familiar, no Município de Monte Negro, Estado de Rondônia.

O Município de Monte Negro está localizado no Estado de Rondônia a oeste da Amazônia Brasileira $\left(10^{\circ} 18^{\prime} \mathrm{Sul} ; 63^{\circ} 14^{\prime}\right.$ Oeste). O município fica a cerca de $250 \mathrm{~km}$ a sudoeste de Porto Velho, capital do Estado, sendo cortado pela BR 421. Monte Negro tem uma população estimada de 13.350 habitantes, dos quais a maioria vivendo de economia rural em pequenas propriedades (CAMARGO et al., 2002).

Segundo estimativas da Agência de Defesa Sanitária Agrosilvopastoril do Estado de Rondônia (IDARON), no ano de 2003, o Município de Monte Negro contava com efetivo ovino de, no máximo, 2.000 animais, na grande maioria sem raça definida, mantidos como criações de subsistência. Considerando prevalência estimada de $50 \%$, precisão mínima de $10 \%$ e intervalo de confiança de $95 \%$, chegou-se ao número mínimo 96 animais a serem testados, sendo coletadas 141 amostras por segurança. As fazendas visitadas compuseram propriedades envolvidas em estudo anterior, que avaliou a prevalência de anticorpos anti-Leptospira spp. em bovinos (AgUIAR et al., 2006). Nessa ocasião visitou-se 86 fazendas que representam a totalidade de propriedades criadoras de bovinosem MonteNegro, das quaisem 15 fazendas havia criação de ovinos. A determinação do tamanho da amostra e o cálculo de prevalência animal foram obtidos com auxilio do programa EpiInfo 6.04.

As colheitas de sangue foram efetuadas por venopunção da jugular entre maio e outubro de 2003. Os soros foram obtidos após a retração do coágulo e estocados a $-20^{\circ} \mathrm{C}$ até o momento da realização dos exames de Soroaglutinação Microscópica (SAM), realizados em microplacas com leitura direta com objetiva de longa distância (GALTON et al., 1965; Cole Junior et al., 1973), frente a uma coleção de 24 antígenos constituídos por sorovares de leptospiras vivas, cultivadas em meio líquido de EMJH modificado com estirpes de referência representantes dos sorogrupos: Andamana, Australis, Autumnalis, Bataviae, Bratislava, Butembo, Canicola, Castellonis, Cinoptery, Copenhageni, Grippotyphosa, Hardjo, Hebdomadis, Icterohaemorrhagiae, Javanica, Panama, Pomona, Patoc, Pyrogenes, Sentot, Shermani, Tarassovi, Wolffi e Whitcombi. Osorovar considerado como o mais provável de provocar a infecção foi o que apresentou maior título no exame. Os animais que apresentaram dois ou mais sorovares com títulos idênticos (coaglutinação) foram excluídos desta análise, sendo considerados apenas como reatores para a Leptospira spp. O ponto de corte para a triagem foi a diluição de 1:100 (FAVERO et al., 2002).

Tabela 1 - Prevalência de anticorpos anti-Leptospira spp. em ovinos do Município de Monte Negro, RO. segundo sorovares reatores. Colheitas efetuadas entre maio e outubro de 2003.

\begin{tabular}{lccc}
\hline Sorovar & Ovinos positivos & Título $\left(\mathrm{n}^{*}\right)$ & Prevalência (IC 95\%) \\
\hline Patoc & 14 & $100(4), 200(9), 400(1)$ & $29,7(18,0-43,9)$ \\
Autumnalis & 7 & $100(5), 200(2)$ & $14,8(6,7-27,5)$ \\
Pyrogenes & 5 & $200(4), 400(1)$ & $10,6(4,0-22,1)$ \\
Australis & 2 & $200(1), 400(1)$ & $4,2(0,7-13,3)$ \\
Bratislava & 2 & $100(1), 200(1)$ & $4,2(0,7-13,3)$ \\
Hardjo & 2 & $200(1), 400(1)$ & $4,2(0,7-13,3)$ \\
Icterohaemorrhagiae & 2 & $100(1), 200(1)$ & $4,2(0,7-13,3)$ \\
Castellonis & 1 & $200(1)$ & $2,1(0,1-10,0)$ \\
Hebdomadis & 1 & $100(1)$ & $2,1(0,1-10,0)$ \\
Coaglutinação & 11 & $100(4), 200(6), 400(1)$ & $23,4(12,9-37,0)$ \\
\hline Total & 47 & $100(16), 200(26), 400(5)$ & $33,3(25,9-41,4)$ \\
\hline
\end{tabular}

*Número de animais reatores para os sorovares e título. 
Doze propriedades $(80,0 \%)$ apresentaram pelo menos um animal reagente. Quarenta e sete animais apresentaram títulos de anticorpos iguais ou superiores a 100 (33,3\%; IC 95\% 25,9-41,4\%). Os sorovares detectados foram:Patoc (29,7\%), Autumnalis (14,8\%), Pyrogenes $(10,6 \%)$, Australis $(4,2 \%)$, Bratislava $(4,2 \%)$, Hardjo $(4,2 \%)$, Icterohaemorrhagiae $(4,2 \%)$, Castellonis (2,1\%) e Hebdomadis (2,1\%). Em 11 $(23,4 \%)$ animais não foi possível a determinação do sorovar mais provável, pois houve coaglutinações com títulos mais elevados idênticos para dois ou mais sorovares envolvidos na reação. A Tabela 1 apresenta as frequências observadas por sorovares reatores e seus respectivos títulos.

O presente trabalho apresenta a prevalência de anticorpos anti-Leptospira spp. em ovinos do Município de Monte Negro, Estado de Rondônia, em colheitas de sangue efetuadas no ano de 2003 em animais de propriedades onde se desenvolve a agricultura do tipo familiar. Na região, os ovinos são criados soltos, coabitando pastagens com outras espécies de animais, como bovinos e equinos, o que propicia um maior contato entre as diferentes espécies e pode favorecer a transmissão de agentes infecciosos entre espécies.

Títulos de anticorpos anti-Leptospira spp. superiores a 100 foram observados em 47 ovinos, resultando em prevalência de 33,3\% (IC 95\% 25,9-41,2\%). O número de animais examinados, embora pequeno, representa a população de ovinos criados no presente município. Das 15 propriedades envolvidas no presente estudo, $12(80 \%)$ apresentaram animais sororeagentes, demonstrando que a infecção de ovinos por leptospiras apresenta-se disseminada na região. Este resultado corrobora com pesquisa anterior realizada no rebanho bovino da mesma região, onde AgUiAR et al. (2006) observaram 95\% das propriedades $(82 / 86)$ apresentando pelo menos um bovino sororeator para leptospiras.

O sorovar Patoc foi o mais frequente com 29,7\% das reações. No entanto, $23,4 \%$ das reações sorológicas apresentaram coaglutinação, não sendo possível a identificação de um sorovar com maior título. $\mathrm{O}$ sorovar Patoc é um sorovar de Leptospira biflexa, apatogênico e de vida livre, entretanto é utilizado como marcador sorológico, pois costuma reagir precocemente, e apresenta reações cruzadas com sorovares patogênicos. O sorovar Hardjo, reconhecido como responsável por perdas econômicas em ruminantes em todo mundo, foi responsável por $4,2 \%$ das reações sorológicas, contrastando com os resultados obtidos por AguiAR et al. (2006) em bovinos da mesma região, onde o sorovar Hardjo foi o mais frequente nos animais e nas propriedades $(14,5 \mathrm{e}$ $45 \%$, respectivamente).

O presente estudo alerta para a possibilidade de infecção no homem, tendo em vista as caracte- rísticas regionais de fronteira agrícola amazônica. Em avaliação anterior dos humanos que habitam as propriedades em estudo, Aguiar et al. (2007) encontraram as maiores frequências de anticorpos para os sorovares Patoc e Autumnalis, sugerindo uma possível fonte de infecção comum entre as espécies estudadas, visto a semelhança encontrada na espécie ovina. Entretanto, novas pesquisas necessitam ser delineadas para melhor entendimento dos aspectos epidemiológicos da infecção por Leptospira spp. na região da Amazônia ocidental brasileira.

\section{AGRADECIMENTOS}

Ao Conselho Nacional de Desenvolvimento Científico e Tecnológico (CNPQ) pelas bolsas de produtividade de M.B. Labruna, S.A. Vasconcellos e S.M.M. Gennari.

\section{REFERÊNCIAS}

ACHA, P.N.; SZYFRES, B. (Ed.). Zoonosis y enfermedades transmisibles comunes al hombre y a los animales: bacterioses e micoses. Washington: OPAS, 2001. 416p.

AGUIAR, D.M.; GENNARI, S.M.; CAVALCANTE, G.T.; LABRUNA, M.B.; VASCONCELLOS, S.A.; RODRIGUES, A.A.R.; MORAES, Z.M.; CAMARGO, L.M.A. Seroprevalence of Leptospira spp. in cattle from Monte Negro Municipality, Western Amazon, Brazil. Pesquisa Veterinária Brasileira, v.26, n.2, p.102-104, 2006.

AGUIAR, D.M.; CAVALCANTE, G.T.; CAMARGO, L.M.A.; LABRUNA, M.B.; VASCONCELLOS, S.A.; SOUZA, G.O.; GENNARI, S.M. Anti-Leptospira spp. and anti-Brucella spp. antibodies in humans from rural area of Monte Negro municipality, state of Rondônia Brazilian western Amazon. Brazilian Journal of Microbiology, v.38, p.93-96, 2007.

CAMARGO, L.M.A.; MOURA, M.M.; ENGRACIA, V.; PAGOTTO, R.C.; BASANO, S.A.; SILVA, L.H.P.; CAMARGO, E.P.; BEIGUELMAN, B.; KRIEGER, H. A rural community in a Brazilian Western Amazonian region: some demographic and epidemiological patterns. Memórias do Instituto Oswaldo Cruz, v.97, p.193-195, 2002.

COLE JUNIOR, J.R.; SULZER, C.R.; PURSELL, A.R. Improved microtechnique for the leptospiral microscopic agglutination test. Applied Microbiology, v.25, p.970-980, 1973.

FÁVERO, A.C.M.; PINHEIRO, S.R.; VASCONCELLOS, S.A.; MORAIS, Z.M.; FERREIRA, F.; FERREIRA NETO, J.S. Sorovares de leptospiras predominantes em exames sorológicos de bubalinos, ovinos, caprinos, eqüinos, suínos e cães de diversos estados brasileiros. Ciência Rural, v.32, n.4, p.613-619, 2002. 
GALTON, M.M.; SULZER, C.R.; SANTA ROSA, C.A; FIELDS, M.J. Application of a microtechnique to the agglutination test for leptospiral antibodies. Applied Microbiology, v.13, p.81-85, 1965.

HERRMANN, G.P.; LAGE, A.P.; MOREIRA, E.C.; HADDAD, J.P.A.; RESENDE, J.R.; RODRIGUES, R.O.; LEITE, R.C. Seroprevalence of agglutinins anti-Leptospira spp. in sheep from the Southeast and Southwest
Mesoregions of the state of Rio Grande do Sul, Brazil. Ciência Rural, v.34, n.2, p.443-448, 2004.

RADOSTITS, O.M.; GAY, C.C.; BLOOD, D.C.; HIN-

CHCLIFF, K.W. (Ed.). Veterinary medicine. Philadelphia: Saunders, 2000. 1877p.

Recebido em 19/5/09

Aceito em 13/7/10 